\title{
An Early Photographic View of Auckland
}

Shaun Higgins

Keywords: \#ambrotype \#photographic view of Auckland \#Hartley Webster \#John Nicol Crombie \# urban landscape \# dating photographs

An ambrotype photographic view of Auckland presents one of the earliest extant photographs of the urban landscape in the city. As a rare example of a landscape presented as a cased image it marks an early scenic view that would be repeated in later technology. Identification and supporting evidence dates the cased photograph to circa 1857. Of the photographers working in Auckland at that time two primary candidates for the creation of this work are discussed, Hartley Webster and John Nicol Crombie with the argument that the former is the most likely. Several other photographic views from 1858 to 1859 are shown as examples of known early landscape photographs of Auckland. One in particular shows a wider view taken from a similar point on Constitution Hill looking across to Mechanics Bay and Parnell. 
Early photographic views of Auckland are rare. Most of the early record comes from wet plate photography in the form of albumen silver prints made from collodion glass plate negatives. Though photography was practiced in Auckland as early as 1848 , most outdoor scenes were taken in the 1860s with only a few known earlier examples from 1858 and 1859.

Auckland War Memorial Museum recently acquired an ambrotype that predates other known Auckland landscape photographs. This early view offers a glimpse into the period before photographs on paper became commonplace. It is exceedingly rare to find such outdoor views presented in morocco cases (leather on wood with a brass mat over glass inside) as these were commonly reserved for portraiture. Such a picture could be an experiment, perhaps testing new technology, or for a particular client request given landscape photography was not common. Such a picture could be sent back to the United Kingdom to show Auckland.

Photographers made use of a range of technologies and formats, adapting to new media as they became available. Daguerreotypes began to fall out of favour by the mid-1850s due to the emergence of collodion positives known as ambrotypes. An underexposed collodion negative appears in positive when viewed against a black background. This enabled the creation of a visible image on glass without the hassle associated with creating a daguerreotype. Like daguerreotypes, ambrotypes yielded only one photograph. But ambrotypes were cheaper than daguerreotypes with the added advantage of fitting the existing mounts and cases. A third early option which was contemporaneous with the daguerreotype was the salt print from calotype (or Talbottype) paper negatives. Unfortunately thus far only late 1850 s examples such as $1858 / 59$ salt prints appear to have survived, though there is mention of calotype views of scenes in the Wellington region a little earlier ${ }^{1}$ and some suggestion of use of the process in Auckland in association with an early daguerreotypist ${ }^{2}$, likely to be Hartley Webster. John Nicol Crombie also produced albumenized salt prints (salt prints varnished with a thin coating of albumen) in the early 1860 s. $^{3}$

The recently acquired ambrotype features a view of Mechanics Bay seen from the vantage point of Constitution Hill. Parnell buildings are visible on the hill above and a waka can be seen near the shore. In the centre is an enclosed area for shipbuilding.

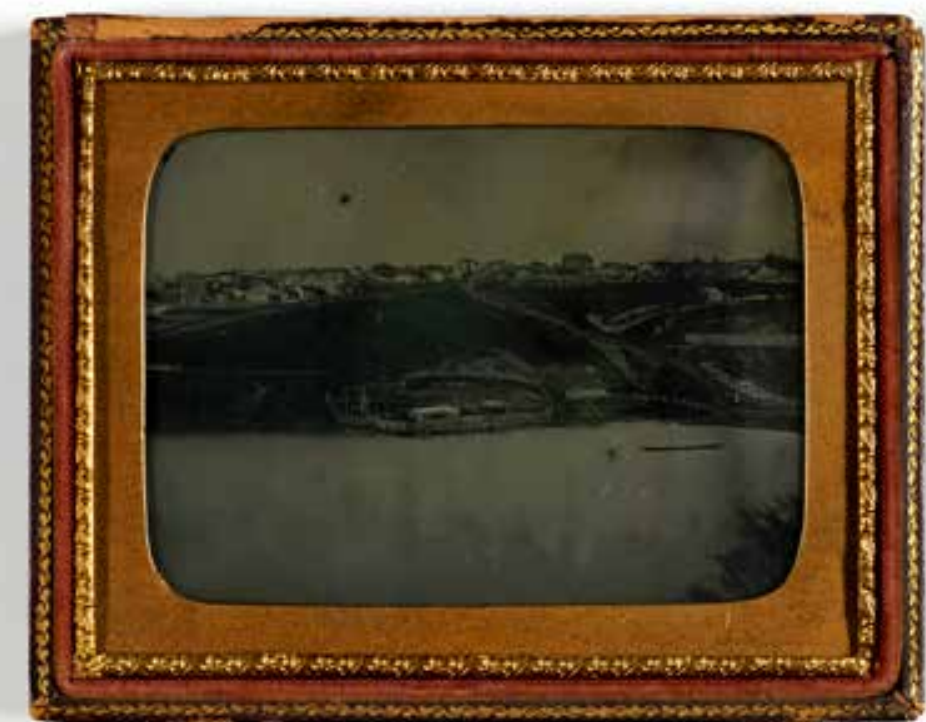

\section{DATING THE MECHANICS BAY AMBROTYPE}

In 1862 John Nicol Crombie stated with regard to photography in New Zealand, "we commenced with the daguerreotype early in 1847, and adhered to it pertinaciously up to 1857 , when we got to glass positives." This provides a useful starting date range which should be expanded to include 1856 as Montague Scott had brought the "improved collodion process" with him to Auckland in October 1855 and briefly advertised up until 6 February 1856 citing supply problems before he moved on. ${ }^{5}$ Ambrotypes were produced into the early 1860 s and overlap with collodion wet plate negative use in general.

Like many ambrotype examples, this one is cased. Although incomplete, the case is useful in attempting to date the item as certain components fall within periods of known use. Analysis of periods of use can be applied to most aspects of the case following patterns observed in the United States. By 1853 the United States was producing over three million daguerreotypes a year. ${ }^{6}$ Britain was regularly using the United States as a source of cases, importing them from the vast market on the east coast.' Many of the cases used in New Zealand at this time would also have been of American make, even if acquired in England. Shipping would have created a time delay so any dates based on the United States chronology should be understood with this in mind. 
The Mechanics Bay ambrotype is housed in a smooth double elliptic mat that dates from 1848 to $1858 .{ }^{8}$ Other features such as the floral pattern preserver can be found in use from 1851 to $1859^{\circ}$ and the case gilding pattern falls within the 1850 to 1862 range..$^{10}$ The geometric case cover pattern dates to $1852 .{ }^{11}$ It is important to note that a plate could be removed from one case and placed in another, making it difficult to find a specific date correlation between them. However such examples can still be identified by comparison of dates of the mat, preserver and case. It is unlikely that these three dates will agree if they are not original to the image. ${ }^{12}$

The combined evidence from the case presents a date range of 1852 to 1858 . The case was probably a stock item intended for mounting daguerreotypes and simply applied to the new medium. This date range accomodates Crombie's comments on photographers' adoption of glass positives in 1857 . It is likely the ambrotype was made from 1856 to 1858 (circa 1857).

Ambrotypes are typically laterally reversed which is one of the reasons they were predominantly used in portraiture where the reversa was less apparent. This Auckland scene does not appear in mirror reverse suggesting the plate is mounted backwards with the emulsion to the back which would place it against the black backing.

\section{THE BAY AND SHIPYARD}

Mechanics Bay was named as the residential district for labourers, artisans and mechanics. ${ }^{13}$ William Swainson described the bay in 1853 as, "yet but little built upon; a large rope-walk, a ship-builders' yard, a native hostelry, and a few small shops, are the only buildings." ${ }^{\prime 14}$ He goes on to explain that the bay was the principal place of encampment for Māori visiting Auckland by waka, landing produce. This was a major source of fruit and vegetables for the Auckland population. For example, he states that, "during the present summer 1200 kits (of peaches) were brought into Auckland by canoes alone."15 Principal traders have been noted as Ngāti Pāoa and Ngāti Maru from the Hauraki. ${ }^{16}$ The produce was often sold on the main wharf ${ }^{17}$ in Commercial Bay where foot traffic was more frequent.

The ship-builders' yard Swainson refers to is H. Nicol's shipyard. It is enclosed by a fence in this image with perhaps one vessel under construction and two covered piles of wood. An 1858 view of this site
(Figure 2) shows an expanded shipyard with multiple vessels under construction and the fence to the left removed. The progress visible in the 1858 print suggests the ambrotype is of an earlier date as a ship is now shown out to the left beyond where the fence was.

\section{PROVENANCE}

Provenance is the final part of the story of the Mechanics Bay ambrotype. The cased photograph was found in an English county sale. The owner had no notion of what it was or where it was from. As the 1858 series of photographic views of Auckland by Hartley Webster were intended to be sent home (to the U.K.), ${ }_{1}^{18}$ it is possible the earlier ambrotype travelled to England in a similar manner. Mr and Mrs Webster left Auckland for England in December 1860,19 arriving in London in 1861. It is conceivable that some items such as the small ambrotype were taken to England as gifts for family or perhaps even for sale. Giles notes Webster's advertised intention to do business in London, albeit in procuring goods for his return to New Zealand. ${ }^{20}$ In particular an 1860 reference to "take charge of Pictures to London free of expense, and forward them to any part of the world"21 certainly implies awareness of the interest for pictures from New Zealand back in England.

John Nicol Crombie also spoke of his views of Auckland being, "well adapted to give friends at home a correct impression of the Metropolis of New Zealand" in his earlier 1856 advertisement. ${ }^{22}$ Crombie himself also eventually returned to England.

If the ambrotype was not retained when taken but instead sold as an early Auckland landscape, the new owner could have similarly taken or sent it to England. To immigrants such pictures would have been a way of showing families their new home. Unfortunately the provenance stops with the county sale and it is doubtful any further evidence exists.

\section{ATTRIBUTION: HARTLEY WEBSTER}

In October 1858 the newspaper New Zealander featured a piece on "Photographic Views of Auckland". ${ }^{23}$ These scenes were taken by the 
Auckland photographer Hartley Webster who had established himself as a daguerreotypist in 1852 . Of the twelve plates representing the city and suburbs, two are from Parnell, "from the Point right up to Mr. Kinder's house near the Grammar School". ${ }^{24}$ It was said that many of these would soon be sent to "old friends at home," as evidence of "what sort of place Auckland is."

Unsurprisingly, few of these works survive in New Zealand as most were indeed likely sent back to the United Kingdom. Hartley Webster's feature mentions Mr Kinder's house and it is in one of the Reverend John Kinder's albums that a photograph matching one of these descriptions can be found today. The two men could have easily been acquainted with one another. Kinder was painting landscapes at this time so it is quite likely that he would have taken an interest in Webster's outdoor work. It is possible that Kinder may have later purchased albumenized paper from Webster's stock for his own photography. ${ }^{25}$

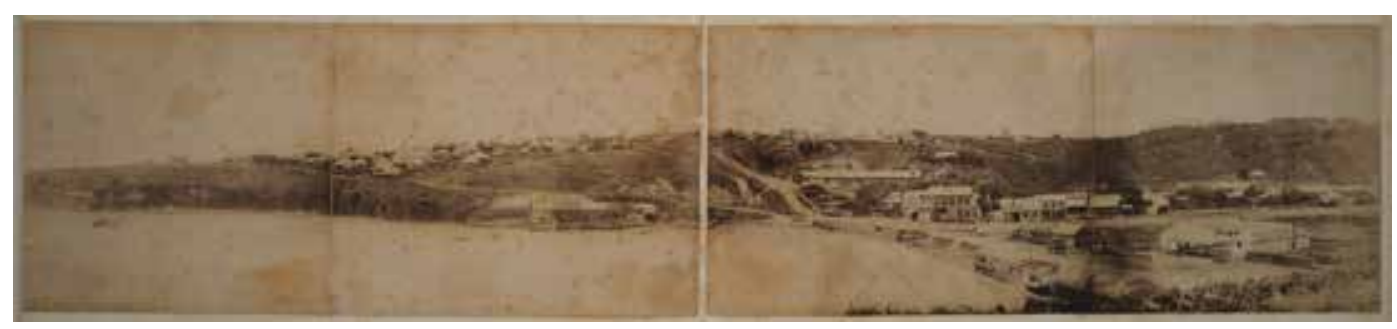

Figure 2, Hartley Webster. Mechanics Bay and Parnell. from Constitution Hill. Salt print in album, 1858. Print size 153 $\mathrm{mm} \times 719$ mm. PH-ALB-88p36-37, Auckland War Memorial Museum - Tāmaki Paenga Hira.

The caption in Kinder's album, written in Kinder's hand reads, "Mechanics Bay and Parnell. from Constitution Hill. ${ }^{26}$ Photo by Webster." In 1977 Main noted that, "the first landscape we can positively identify with Webster is a panorama of Mechanics Bay and Parnell taken from Constitution Hill." The date given by Main is October 1858, the date of the New Zealander article.

Webster's panoramic view consists of prints from four plates placed side by side to form a panorama. The prints are not varnished and present no sheen suggesting either an early style of diluted albumen that produced a matte surface similar in appearance to salt prints or that they are actual salt prints. ${ }^{27}$ With the adoption of collodion negatives there was initially a backlash against shiny albumenized paper as many people were used to the matte finish of salt prints. ${ }^{28}$ By the 1860 s this finish had fallen out of fashion in favour of the albumen silver semi-gloss sheen.
The two central frames of the Mechanics Bay panorama are very similar to the ambrotype view of Mechanics Bay suggesting the photographs were taken from a similar position on Constitution Hill. As the image is comprised of multiple plates there is significantly more room in which to capture the landscape to either side of Parnell Rise.

Looking at the subject of landscape, in Kinder's watercolours one can certainly see aspects of composition that follow a similar style to early photographic views. The use of a strong building or feature in a realistic rendition of a landscape has been tied to influences in Victorian art and writing such as the work of John Ruskin. ${ }^{29}$ Brownson wrote that John Kinder's photographs are some of the first images to seize the experience of living in New Zealand, showing what is unique about this place. ${ }^{30}$ In this light we can see why Kinder was interested in Webster's photograph. The Webster panorama seems caught in an eerie silence as it shows a scene filled with the detailed evidence of a growing city, suburb and shipyard yet depicts only a few figures seated in the hostelry to the right. It is also a place which accommodates some of the recognisable features found in Kinder's works such as St Stephen's Church on open grassland to the left, found in his watercolour painted in the same year, $1858 .{ }^{31}$

\section{JOHN NICOL CROMBIE}

Another prominent photographer was also working in Auckland at the time the new collodion process in ambrotypes and negatives became available. John Nicol Crombie photographed a series of Auckland views, also presented as prints joined together to create a panorama. Some of these photographs were taken to London as part of the 1862 International Exhibition. ${ }^{32}$ Alongside watercolours by Charles Heaphy and furniture by Anton Seuffert, John Nicol Crombie exhibited several views of Auckland and won an honourable mention for one of his panoramic views. ${ }^{33}$ An earlier mention of two excellent views of Auckland photographed by him in 1859 may refer to the same two panoramic views he took to London in 1862. ${ }^{34}$ One of the views, that of Commercial Bay from Point Britomart, appeared in the Illustrated London News as an engraving in $1860 .{ }^{35}$ Kinder also put the Commercial Bay albumen silver print into his album but credited Webster, showing that even he found it difficult to tell their works apart. Though very similar in format, Mechanics Bay is not listed among the works by Crombie shown at the 1862 International Exhibition. 
In September 1856 Crombie left Auckland to tour the districts south of Auckland. The preceding month he had advertised his imminent departure for the southern provinces. ${ }^{36} \mathrm{He}$ is mentioned as being in Auckland again in 1859. ${ }^{37}$ Main suggests his return date was October $1858,{ }^{38}$ having visited Melbourne where he acquired new photographic skills. This takes him out of Auckland for two years and suggests he switched from daguerreotypes to collodion positives and negatives when he returned. If Crombie made the ambrotype, he either made it within the 15 months prior to September 1856, since he first arrived in New Zealand in 1855, or after October 1858. Main's reference to Crombie's statement that they "got to glass positives" in 1857 would suggest the earlier date is unlikely. ${ }^{39}$

Regarding Crombie's work prior to his 1856 departure from Auckland it is worth noting an interesting advertisement from July 1856. In addition to portraits he mentions "views of Auckland, embracing Shortland, and West Queen-streets, Chapel Hill, \&c." ${ }^{\prime 40}$ This leaves a small window of time for such works but also suggests the possibility of further works that could be a different format altogether, perhaps even calotypes.

Crombie's absence from Auckland for most of the date range suggests the Mechanics Bay ambrotype is not his work. The short period in 1856 remains the only possibility in Crombie's case before the changes visible in Webster's 1858 panorama (Figure 2).

\section{OTHER EARLY VIEWS OF AUCKLAND}

When Crombie returned from the provinces south of Auckland he moved his studio from Shortland Street to Queen Street. The former studio was taken over by Bruno L. Hamel in $1859^{41}$ and he also had an interest in taking pictures of outdoor scenes. By this time both photographers were producing prints from collodion wet plate negatives.

Two salt print views of Auckland can be found in an album of photographic views taken by Hamel in 1859 (Auckland Museum PH-ALB-84). Hamel accompanied Dr. Ferdinand Hochstetter on his Geological Survey of the Auckland Province. The album features several early scenes of Auckland's waterfront and surrounding areas.

Hamel took two scenes from Point Britomart looking across to Commercial Bay. This area would later be reclaimed and the point itself

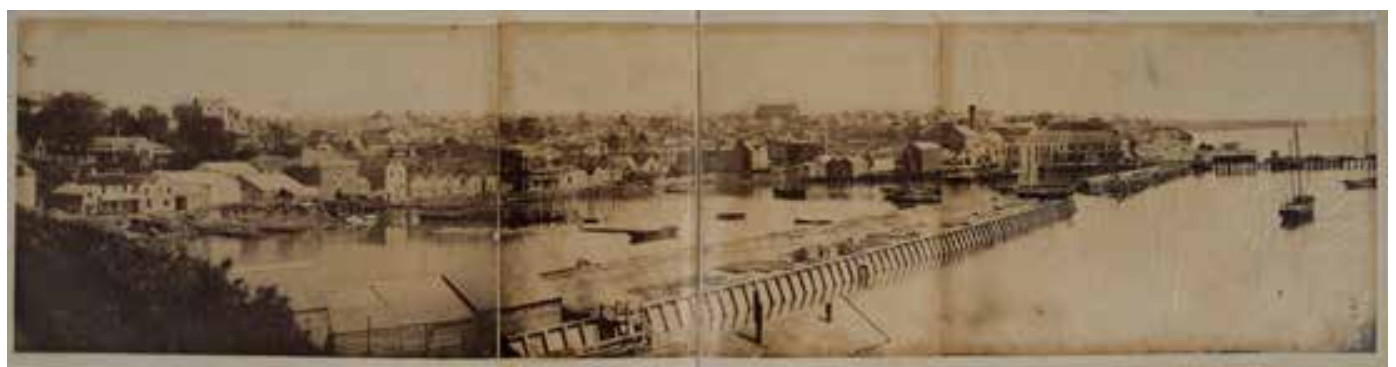

Figure 3, John Nicol Crombie. Commercial Bay from Point Britomart. Albumen silver print in album, 1859. Print size $137 \mathrm{~mm} \times 564 \mathrm{~mm}$. PH-ALB-88p40-41, Auckland War Memorial Museum - Tāmaki Paenga Hira.

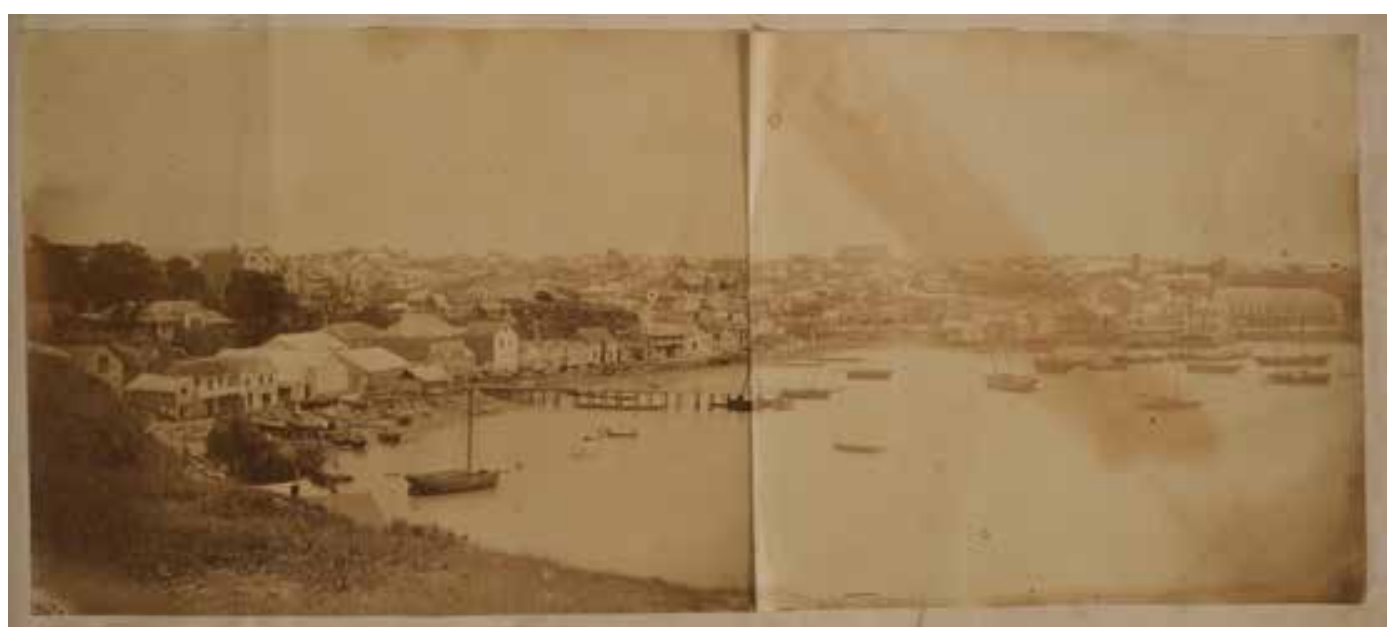

Figure 4, Bruno Hamel. Auckland. Salt print in album. 1859. Print size $116 \mathrm{~mm} \times 159$ mm. PH-ALB-84-p2-1, Auckland War Memorial Museum - Tāmaki Paenga Hiro. 
would disappear altogether as it was cleared and used as infill. The photographer's studio was located close by. This would have simplified the task of shooting wet plate collodion as he could finish work on the plate without a portable dark room. ${ }^{42}$ The first such image consists of two prints put together to form a panorama in a similar style to Crombie. The view shows a busy waterfront seen from a grassy hillside. The second view of Auckland in Hamel's album shows a group of Māori sitting on the point with Commercial Bay behind them and a road across the foreground. The group would not be far from the fort referred to by Swainson as "The Britomart." ${ }^{\text {"43 }}$ The building is possibly represented by the steep earthen slope to the right in the image which could be the earthen parapet as described by Vigors in $1850 .{ }^{44}$

It is possible that more 1850 s photographs of Auckland are still yet to surface and as with the Mechanics Bay ambrotype, they may be abroad. Along with Crombie, W. H. Sutcliffe submitted a photograph to the Illustrated London News ${ }^{45}$ showing an east view of Auckland that was likely was taken around the same time Crombie took his panoramic views. Sutcliffe is noted as active from July 1859 to 1860.46

The Mechanics Bay ambrotype offers an exciting step furthe back in time to the introduction of ambrotypes to Auckland. It is hard to imagine that it stands alone in this category of landscape photography, especially as it was easier to produce than a daguerreotype. Perhaps this work was the inspiration for landscape panoramas such as the award-winning panoramic photography that Crombie took to London in 1862 . Or perhaps it was merely a test shot for Webster's own panorama of 1858, since it was an easier format to work with being both smaller and faster as it did not require printing. The two photographers could have competed with each other or perhaps even exchanged ideas. The available evidence leans towards Webster as the likely photographer. Further works may yet emerge such as those mentioned in the 1856 Crombie advertisment. Either way, this work represents the local emergence of a style of photography that would dramatically increase in the 1860 s as the professional and the amateur alike would take their cameras outdoors. As the only extant ambrotype view of early Auckland this work marks an important step in the development of local photography. Perhaps more examples of early urban landscape photography will emerge in the future taking us back even further to the daguerreotype and calotype period. For the moment, this work is as far back as we can see.

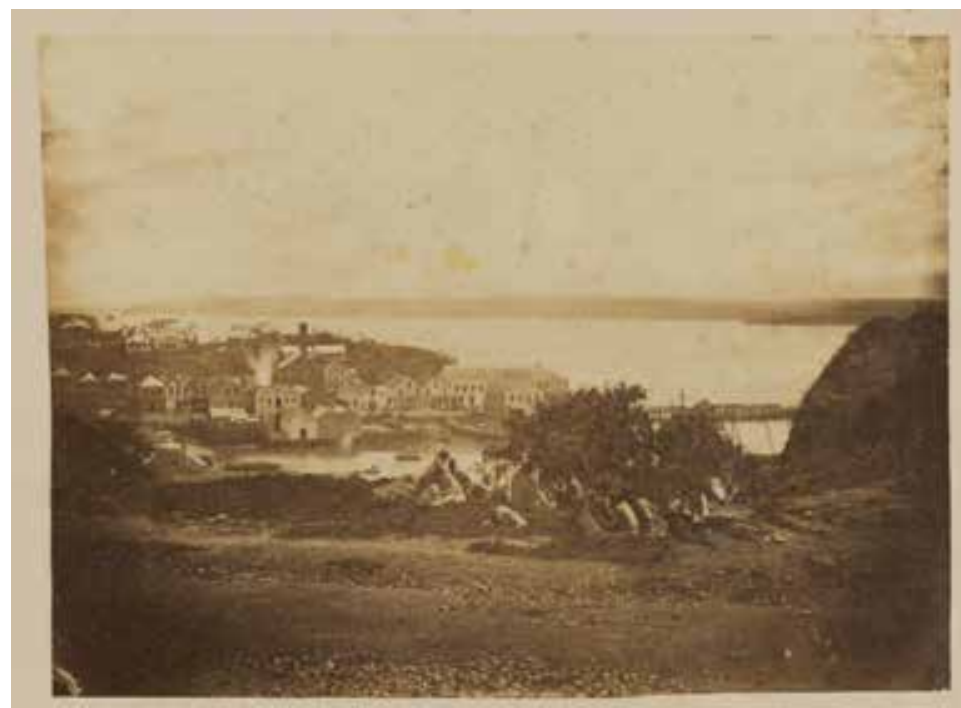

igure 5, Bruno Hamel. Auckland. Salt print in Album. 1859. Print size $12 \mathrm{~mm} \times 259 \mathrm{~mm}$. PH AlB-84-p3-1, Auckland War Memorial Museum Tämaki Paenga Hira.
Figure 6, Illustrated London News. East view of Auckland, from photograph by W. 10 May 1860 . Auckland War Memo. Auckland Tāmaki Paenga Hira.

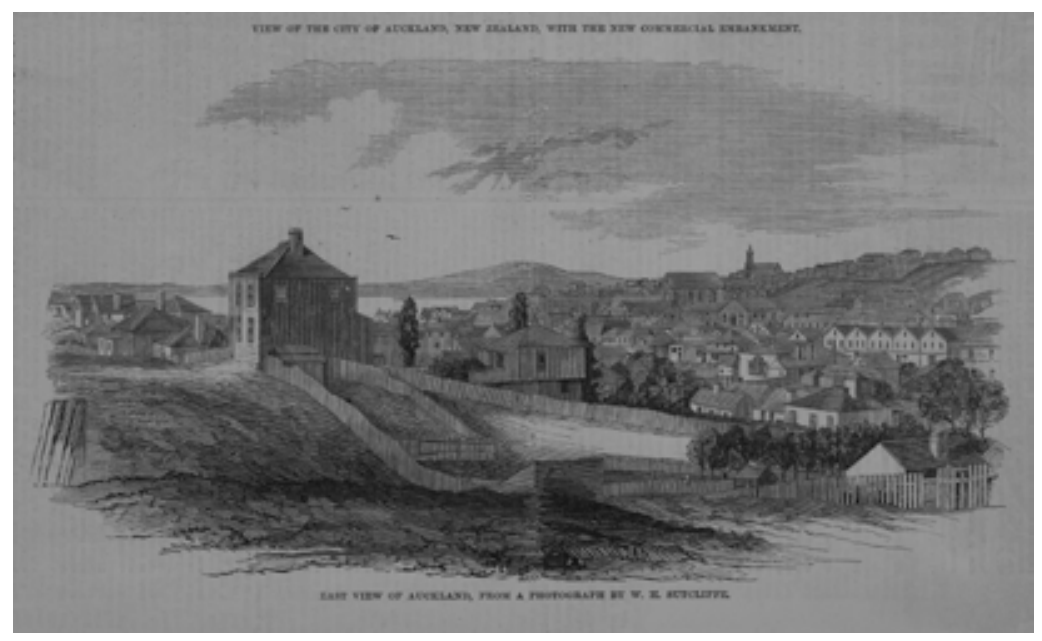




\section{REFERENCES}

Brownson, Ron. John Kinder's New Zealand. Auckland: Random House and Auckland Art Gallery, 2004.

Burns, Stanley B. Mirror, Mirror: The Burns Collection Daguerreotypes. New York: Burns Archive Press, 2012.

Cameron, Carolyn. Mechanics Bay : the first twenty years of European settlement, 1840-1859. Auckland: Carolyn Cameron, 2013.

Hannavy, John. Case Histories: The Presentation of the Victorian Photographic Portrait 1840-1875. Woodbridge, Suffolk: Antique Collectors' Club, 2005.

Giles, Keith. "Hartley Webster: Auckland's first resident professional photographer." NZ Legacy, 20, no.1 (2008): 5-10.

Goulding, Jeanne. "The Ropemakers of New Zealand: the history of Donaghy's Rope and Twine Company Limited." Typescript, Auckland War Memorial Museum MS-1108 (1968).

Graham-Stewart, Michael. Crombie to Burton: early New Zealand photography. Auckland: John Leech Gallery, 2010.

Main, William. Auckland through a Victorian Lens. Wellington: Millwood Press, 1977.

Nolan, Sean. Fixed in Time. Portland, CreateSpace Independent Publishing Platform, 2015.

\section{ENDNOTES}

1 Wellington Independent, "Mr. Hewlings," September 19, 1857, p.2.

2 New Zealander, "Photography," November 25, 1864,p. 4.

3 Michael Graham-Stewart, Crombie to Burton: early New Zealand photography (Auckland: John Leech Gallery, 2010), pp.12-15. Several of Crombie's albumenised salt prints are shown in this catalogue.

4 William Main, Auckland through a Victorian Lens (Wellington: Millwood Press, 1977), p.9.

5 New Zealander, "Montague Scott, Photo-
Nolan, Sean. Fixed in Time (3rd edition). Portland: CreateSpace Independent Publishing Platform, 2017. Daguerreotype Journal Autumn, no.4 (2015): 29-37.

Seiberling, Grace et al. Amateurs, Photography, and the Mid-Victorian Imagination. Chicago: University of Chicago Press, 1986.

Stead, Oliver (ed.). 150 Treasures. Auckland: Auckland War Memorial Museum and David Bateman, 2001.

Stulik, Dusan and Art Kaplan. The Atlas of Analytical Signatures of Photographic Processes: Albumen. Los Angeles: The Getty Conservation Institute, 2013.

Swainson, William. Auckland, the capital of New Zealand, and the country adjacent: Including some account of the gold discovery in New Zealand with a map of the district from recent surveys. London: Smith, Elder \& Co, 1853.

Thorp, Joshua. "Thorp's impressions of the town of Auckland in 1857." Auckland Auckland War Memorial Museum MS-1332, 1857.

Vigors, Philip. "Philip Doyne Vigors - Journal". Typescript from 1850 original. Auckland War Memorial Museum MS-313.
Nolan, Sean. "Dating American Daguerreotypes," twenty years of European settlement, 1840-

graphic Artist, Portrait and Animal Painter", 6 February, 1856,p. 1(supplement)

6 Stanley B. Burns, Mirror Mirror: The Burns Daguerreotypes (New York, : Burns Archive Press, 2012), p.19.

7 John Hannavy, Case Histories: The Presentation of the Victorian Photographic Portrait 1840-1875 (Woodbridge, Suffolk: Antique Collectors' Club, 2005), pp.72-73.

8 Sean Nolan, Fixed in Time (Portland, Oregon, 2015), p.88.

9 Ibid: p.46 Institute, 2013), p.6 \& p.25
10 Ibid: p.52.

11 Sean Nolan, Fixed in Time, 3rd edition (Portland, Oregon, 2017), p.161.

12 Sean Nolan, "Dating American Daguerreotypes," Daguerreotype Journal, Autumn, no.4 (2015)31.

13 Jeanne Goulding, The Ropemakers of New Zealand: the history of Donaghy's Rope and Twine Company Limited (Typescript: 1968, Twine Company Limited (Typer

14 William Swainson, Auckland, the capital of New Zealand, and the country adjacent: Including some account of the gold discovery in New Zealand, with a map of the district from recent surveys (London: Smith, Elder \& Co. 1853), p.28.

15 Ibid: p.71.

16 Carolyn Cameron, Mechanics Bay: The first 1859 (Carolyn Cameron, 2013), p.27.

17 Joshua Thorp, Joshua Thorp's impressions of the town of Auckland in 1857 (Auckland Wa Memorial Museum MS-1332, Auckland,1857), p.4.

18 New Zealander, "Photographic Views of Auckland," 2 October, 1858, p. 3.

19 Keith Giles, “Hartley Webster: Auckland's first resident professional photographer," NZ Legacy 20, no.1 (2008): 9.

20 lbid.

21 Ibid: p.8.

22 Daily Southern Cross, "Ex "Sybil.", July 4, 1856, p. 1.

23 New Zealander, "Photographic Views of Auckland," October 2, 1858, p. 3.

24 lbid.

25 Keith Giles, "Hartley Webster: Auckland's first resident professional photographer," NZ Legacy 20, no.1 (2008): 9.

29 Ron Brownson, John Kinder's New Zealand (Auckland: Random House and Auckland Art Gallery, 2004), p.94.

30 Ibid: p.95.

31 Ibid: p.94

32 New Zealander, "The New Zealand Court of the Exhibition, 1862", August 27, 1862,p. 3.

33 Michael Graham-Stewart, Crombie to Burton: early New Zealand photography (Auckland: John Leech Gallery, 2010), p.5.

34 New Zealander, "Photography", November 25, 1864, p.4.

35 Illustrated London News, "View of the City of Auckland, New Zealand, with the new commercial embankment", 19 May, 1860, p. 473.

36 Nelson Examiner and New Zealand Chronicle, "Opinions of the Metropolitan Press", August 11, 1856,p. 4.

37 New Zealander, "Auckland Race Meeting, $1859^{\prime \prime}$, January 5, 1859,p. 2.

38 William Main, Auckland through a Victorian Lens (Wellington: Millwood Press, 1977), p.7.

39 Ibid, p.9.

40 Daily Southern Cross, "Ex "Sybil", July 4, 1856,p. 1.

41 Michael Graham-Stewart, Crombie to Burton: early New Zealand photography (Auckland: John Leech Gallery, 2010), p.8.

42 Oliver Stead (ed.), 150 Treasures (Auckland: Auckland War Memorial Museum and David Bateman, 2001), p.23.

43 William Swainson, Auckland, the capital of New Zealand, and the country adjacent: Including some account of the gold discovery in New Zealand, with a map of the district from recent surveys (London: Smith, Elder \& Co., 1853), p.31.

44 Philip Vigors, Philip Doyne Vigors - Journa (Typescript from 1850 original Auckland: Auckland War Memorial Museum MS-313, 1850) p.12.

William Main, Auckland through a Victorian Lens (Wellington: Millwood Press, 1977), p.4.

27 Dusan Stulik and Art Kaplan, The Atlas of Analytical Signatures of Photographic Processes: Albumen (Los Angeles: The Getty Conservation

28 Grace Seiberling et al, Amateurs, Photog raphy, and the Mid-Victorian Imagination (Chicago: University of Chicago Press, 1986), p. 34.

45 Illustrated London News, "View of the City of Auckland, New Zealand, with the new commercial embankment," 19 May, 1860,p. 473.

46 William Main, Auckland through a Victorian Lens (Wellington: Millwood Press, 1977), p.170 